\title{
Марина Мудрак
}

\section{КУЛЬТУРНА ДІЯЛЬНІСТЬ УКРАЇНСЬКОї ДІАСПОРИ В СЕРБІї (1991 р. - ПОЧАТОК XXI ст.)}

\begin{abstract}
У 1991 р. починається нова доба для українського народу не тільки в Україні, а й за ї̈ межами. У статті висвітлюються надбання і культурна діяльність української діаспори в Сербії з 1991 до 2012 р., з'ясовано основні напрями діяльності культурно-просвітницьких організацій, товариств, установ, створених українцями на території сучасної Сербії.
\end{abstract}

Ключові слова: українська діаспора в Сербії, освітня діяльність, культурні зв'язки, Товариство української мови, літератури та культури «Просвіта».

Сьогодні громада українців Сербіі $€$ найбільшоюза кількістю ізначенням на Балканах. 3 90-х років XX ст. українці почали інтенсивно відновлювати та створювати у балканських країнах свої національні товариства.

Більшість питань, які порушуються в даному дослідженні, не ставали предметом вивчення українських та зарубіжних науковців. О. Румянцев ${ }^{1}$, В. Чумак ${ }^{2}$ та Г. Саган ${ }^{3}$ вивчають та презентують у своїх працях культурне життя української діаспори в Югославії у контексті презентації українства у світі. Наше дослідження базується на спогадах членів українських товариств $^{4}$, звітах діяльності цих організацій, зокрема Товариства української мови, літератури

\footnotetext{
1 Румянцев О. Становище української громади на території колишньої Югославії з $90-\mathrm{x}$ років ХХ століття до новіших часів // Галичина-Боснія-Воєводина: переселенці з Галичини на території югославських народів в 18901990 pp. 2008. № 5. С. 239-243.

2 Чумак В.В. Україністика в Сербії: лінгвістичний аспект // Слов'янський збірник. 2003. № 10. С. 17-24.

${ }^{3}$ Саган Г.В. Створення та діяльність товариства української мови, літератури і культури Воєводини (Сербія) // Вісник Черкаського університету. Серія: Історичні науки. 2016. № 3-4. С. 130-137; Саган Г.В. Югослов’яни у XX столітті: громадські та культурні зв'язки з Україною / наук. ред. В.М. Даниленко; Київ. ун-т ім. Б. Грінченка; Ін-т української археографії та джерелознавства ім. М.С. Грушевського НАН України. К.: Київ. ун-т ім. Б. Грінченка, 2012. $568 \mathrm{c}$.

4 Кулеба Є. Літні школи україністики // Українське слово: Часопис українців у Югославії з питань культури, літератури та суспільного життя. 2000. № 7. С. 26-27; Терлюк I. Товариство української мови, літератури та культури Воєводини // Українське слово: Часопис українців у Югославії з питань культури, літератури та суспільного життя. 1996. № 1. С. 38-44; Комбіль Я. Відзначення 100-річчя Товариства «Просвіта» // Українське слово: Часопис українців у Югославії з питань культури, літератури та суспільного життя. 2007. № 13. С. 32-33; Сакач С. Союз руснацох и україцох Югославиї од основаня по нєшка // Глас Союзу: Союз русинів і українців Сербії і Чорноropiii. 1997. № 1. C. $2-5$.
}

та культури «Просвіти», Культурно-мистецького українського товариства імені I. Сенюка та інших. Також до написання статті залучені матеріали сайтів Посольства України в Сербії, Світового конгресу українців, Інформаційної служби Товариства «Просвіта» та ін.

Мета статті полягає в окресленні змісту культурної діяльності українських організацій у Сербії наприкінці XX - на початку XXI ст.

Культурна діяльність української діаспори в Сербії має давню історію. Перші українці з'явилися в регіоні у XVIII ст., але як діаспора оформилися наприкінці XIX ст. ${ }^{5}$ За переписом населення, в регіоні після Другої світової війни українська національна меншина не була виділена як самостійна, а розподілена під спільну назву «русини, рутени, українці, малоруси». Тільки після перепису 1971 р. з'явилась окрема колонка "українці» ${ }^{6}$. На сьогодні, за даними перепису населення 2011 р., в Сербії проживає 4903 українці. Регіоном, де проживає найбільша кількість українців у Сербії, є Воєводина 7 .

Після геополітичних зламів у світі на початку 90-х років XX ст., на Балканах почали утверджуватися демократичні зміни, що спонукало українців до відновлення діаспорного життя: засновувалися нові товариства та з'являлися сподівання на кращі умови для розвитку української громади. Разом 3 тим культурну діяльність діаспори почали стримувати югославські війни (1991-1995) та агресія НАТО в Югославії (1999). Проте саме в 90-х роках XX ст. об'єднуються і розгортають свою діяльність сербські українці. Найбільшими осередками культурної та громадської діяльності українців постають такі міста автономного краю

5 Українці в Сербії // Посольство України в Сербії. URL: http://serbia.mfa.gov.ua/ua/ukraine-n/ukrainians-in-n

6 Там само.

7 Таблиця перепису населення Сербії в 2011 році. URL: http://pop-stat.mashke.org/serbia-ethnic2011.htm 
Воєводина, як Новий Сад, Вербас, Кула, Інджія, Сремська Митровиця та інші ${ }^{8}$.

Останнє десятиріччя XX ст. характеризується початком створення та відновлення товариств української діаспори в Сербіі. Українські активісти хотіли заснувати організацію, яка мала $б$ ширші функції та більший вплив на представників громади у контексті збереження та розвитку національних надбань української культури, і власне це стало однією 3 причин заснування у 1989 р. Товариства української мови, літератури і культури Воєводини 9 . Діячі цього товариства досягли прекрасних результатів, зокрема відновлення уроків української мови в школах. Так, у 1991-1992 рр. з'являється україномовне телебачення i радіо, українські гурти беруть участь у фестивалях, встановлюються контакти 3 Україною, запроваджуються літні школи україністики тощо ${ }^{10} .31996$ р. товариство видає журнал "Українське слово» ${ }^{11}$, який став часописом 3 питань культури, літератури та суспільного життя українців в Югославії12. 32001 р. воно існує під назвою «Товариство української мови, літератури та культури “Просвіта"». 3 часом «Просвіта» відкрила свої філії у Великому Бечкереку (сьогодні - Зренянин), Суботиці, Шіду та інших місцях. У Смедереві було засновано Товариство «Кобзар», яке мало драматичні та музичні гуртки. Такі ж гуртки існували в Шабці, Пожаревці, Заєчарі та інших містах. Українська молодь заснувала Товариство студентів.

У жовтні 2007 р. українці Сербії відсвяткували 100-річчя заснування місцевої «Просвіти» на теренах колишньої Югославії ${ }^{13}$. У 1907 р. в українському селі Лішня (Муїнці) у Боснії було засновано читальню українського товариства «Просвіта» як філію львівської «Просвіти».

8 Румянцев О. Становище української громади на території колишньої Югославії з 90 -х років ХХ століття до новіших часів // Галичина-Боснія-Воєводина: переселенці з Галичини на території югославських народів в 1890 1990 pp. 2008. № 5. С. 239-243.

9 Саган Г.В. Створення та діяльність Товариства української мови, літератури і культури Воєводини (Сербія) // Вісник Черкаського університету. Серія: Історичні науки. 2016. № 3-4. C. 130-137.

10 Кулеба Є. Літні школи україністики // Українське слово: Часопис українців у Югославії з питань культури, літератури та суспільного життя. 2000. № 7. С. 26-27.

11 Сербія // Світовий конгрес українців. URL: http:// ukrainianworldcongress.org/news.php/group/31/lang/ua

12 Слово до співвітчизників та друзів. 3 першим числом часопису // Українське слово: Часопис українців у Югославії з питань культури, літератури та суспільного життя. 1996. № 1. С. 7-14.

13 Українці Сербії відсвяткували 100-річчя заснування місцевої «Просвіти» // Закарпаття онлайн. Дата оновлення: 31.10.2007. URL: http://zakarpattya.net.ua/ News/14806-Ukraintsi-Serbii-vidsviatkuvaly-100-richchiazasnuvannia-mistsevoi-Prosvity
У рамках святкування 100-річчя, яке проходило у м. Кула, відбувся вечір з музичною програмою та розвагами ${ }^{14}$. На святах були офіційні делегації Львівської та Тернопільської областей, представники Всеукраїнського товариства «Просвіта» ім. Т. Шевченка. Також прибули представники українських громад та інституцій з Боснії і Герцеговини, Хорватії та інших місць компактного проживання українців ${ }^{15}$.

У 1990 р. було засновано Союз русинів i українців Югославії. Насамперед Союз мав на меті об’єднати громади русинів і українців та запровадити культурницький діалог між ними у діаспорі. Також він сприяв вивченню рідної мови у школах, скеровував місцевих студентів до вищих навчальних закладів України, поширював українознавство серед русинів. У 1997 р. в м. Новий Сад починають видавати вісник «Голос Союзу» ${ }^{16}$. Союз пропонував заснувати єдину національну раду для русинів і українців Югославії. Однак 2 листопада 2002 р. було створено окрему Національну раду русинської національної меншини, а після неї, 17 травня 2003 р., Національну раду української національної меншини Сербії. Українська рада отримала державне фінансування та сьогодні є офіційним представником і захисником інтересів українців у Сербіï.

У Воєводині, в м. Кула, діяльність українських культурних осередків започаткував Євген Кулеба. У середині 80-х років ХХ ст. Культурно-мистецьке українське товариство ім. I. Сенюка розгорнуло активну співпрацю 3 радянською Україною. На запрошення товариства до Воєводини приїжджали ансамблі «Волинянка», «Львівські музики», «Галичина» ${ }^{17}$. У 1990 р. творчі колективи товариства вперше виступили в Україні у Львові, Луцьку, Новому Роздолі. Спостерігаючи за хронологією діяльності товариств у м. Кула, бачимо, що у 1994 р. відновлено уроки української мови, а в 1998 р. активізувалася діяльність Культурно-мистецького товариства ім. I. Сенюка.

У сербському м. Вербас на початку 1990-х визріває ідея заснування українського товариства, котре стало б не тільки носієм культурного життя,

14 Терлюк I. Товариство української мови, літератури та культури Воєводини // Українське слово: Часопис украінців у Югославії з питань культури, літератури та суспільного життя. 1996. № 1. С. 38-44.

15 Комбіль Я. Відзначення 100-річчя Товариства «Просвіта» // Українське слово: Часопис українців у Югославії з питань культури, літератури та суспільного життя. 2007. № 13. C. $32-33$

16 Сакач С. Союз руснацох и україцох Югославиї од основаня по нєшка // Глас Союзу: Союз русинів і українців Сербії і Чорногорії. 1997. № 1. С. 2-5.

17 Саган Г.В. Югослов'яни у XX столітті: громадські та культурні зв'язки з Україною: моногр. К. : Київ. ун-т ім. Б. Грінченка, 2012. С. 350 
але й оберегом національної свідомості. Таким чином, 6 жовтня 1990 р. починає працювати культурно-мистецьке товариство «Карпати». Діяльність товариства спрямовувалася на збереження та розвиток української культури, звичаїв і мови, а також культурних надбань інших народів. Спочатку у товаристві працювало багато активістів різних народностей, які любили українські пісні, танці й мову. Згодом, у 1997 р., тут відновлено вивчення української мови у школах.

У Сремській Митровиці в 1997 р. відновило свою діяльність українське товариство «Коломийка». Проте зареєстровано його було лише в 2003 р., тоді ж було розпочато вечірні курси української мови. У м. Інджія українське товариство «Калина» починає свою діяльність тільки в 2005 р. Сфера діяльності нових організацій - формування ідентичності, розвиток освіти, набуття українською громадою самобутності та рівноправності, співпраця 3 українськими та іншими товариствами, влаштування студентів громади до українських навчальних закладів тощо.

Невід’ємною частиною української культури в Сербії $€$ щорічний фестиваль «Калина», що проводиться з 2003 р. Неможливо не згадати саме 11-й фестиваль 2012 р., який проходив у Вербасі. Як і попередні, він зачарував своєю неповторністю та красою українських пісень, танцю і національних костюмів. Програма того року була різноманітною і цікавою, багатою на фестивальні заходи, але найбільш успішним та масовим був урочистий концерт 11-го фестивалю української культури «Калина - 2014». В урочистому концерті свою майстерність продемонстрували аматори культурно-мистецьких товариств 3 Сербї: Культурно-просвітне товариство «Карпати» 3 Вербасу, Український культурний центр «Кобзар» 3 Нового Саду, Товариство плекання української культури «Коломийка» зі Сремської Мітровиці, Культурно-мистецьке товариство «Калина» 3 Інджії та фольклорний ансамбль Будинку культури Вербаса. Також в урочистому концерті виступили колективи з Липовлян (Хорватія) і Прнявора (Боснія і Герцеговина). Культурно-мистецьке товариство ім. Івана Сенюка 3 м. Кула представило глядачам чудову програму - пісні змінювалися танцями, звучали українські мелодії, а глядачі нагороджували виконавців щирими оплесками ${ }^{18}$.

Діяльність товариств української діаспори надзвичайно колоритна та сповнена українського духу. Дотримуючись традиції, українська громада

18 11-й фестиваль української культури «Калина». 2 частина // КМТ ім. Івана Сенюка. Дата оновлення: 15.06.2014. URL: https://www.ivansenjuk.com/11-i\%D0\%B9festival\%D $1 \% 8$ C-ukra\%D $1 \% 97$ ns $\%$ D $1 \% 8$ Cko $\%$ D $1 \% 97$ kul\%D1\%8Cturi-kalina-2-castina/
Сербії кожного року у березні влаштовує Дні Т. Шевченка та проводить літературні вечори, присвячені Кобзареві. Традиція святкування триває вже понад 40 років, таким чином, українська громада в Сербії надала Шевченківськім дням рівень національного значення. Координатором та головним організатором Днів Тараса Шевченка в Сербії виступає Товариство української мови, літератури і культури «Просвіта» спільно 3 українськими культурно-мистецькими та просвітніми об’єднаннями. У Сремській Митровиці організатором $є$ Товариство плекання української культури «Коломийка», у Вербасі Культурно-просвітнє товариство «Карпати», у Кулі - Культурно-мистецьке товариство ім. Івана Сенюка, у Іджії - Культурномистецьке товариство «Калина» тощо. Кожного року їх відвідує численна українська громада. Активними учасниками цих заходів є школярі, які вивчають українську мову, юнаки та дівчата, котрі студіюють українську філологію у вишах, групи та колективи, що плекають та поширюють культурну спадщину українського народу ${ }^{19}$.

У 2006 р. у Новому Саді Товариство української мови літератури і культури «Просвіта» у співпраці 3 радіо «Novi Sad» у студіï «M» організували публічний запис програми Днів Т. Шевченка. Для продукції українських програм телебачення та радіо було записано пісні та вірші на слова Т. Шевченка у виконанні культурних товариств з Кули, Вербаса та Сремської Митровиці.

Українські програми, газети та журнали також набувають розвитку та поширення в Сербіі. Надзвичайно важливою подією в житті української громади стало відновлення 2005 р. газети «Рідне слово», яка існувала в 1933-1941 pp. серед українців Боснії, а сьогодні щомісячно друкується у Воєводині та розповсюджується серед слов'янських країн на Балканах. Відновлення цієї газети українцями Сербії свідчить про те, що ця громада сьогодні вважає себе безпосереднім спадкоємцем культури боснійських українців. Також українською мовою друкується дитячий журнал «Соловейко». Радіопрограми українською мовою транслюють регіональні радіостанції в містах Вербас, Кула, Інджія, Сремська Митровиця та воєводинська компанія Радіо і телебачення Воєводини (РТВ) 3 міста Новий Сад. Українською редакцією РТВ щотижня транслюються дві україномовні телепередачі. Окрім того, на території Воєводини періодично транслюються півторахвилинні щоденні інформаційні телепередачі українською мовою із сербськомовними титрами.

19 Гочак М. В Сербії відбулися Дні Тараса Шевченка // Інформслужба Товариства «Просвіта». URL: http:// eukrainians.net/prosvita/sevcenko_mitrovica_06/ 
Вартозазначити,що культурно-освітніпотреби української національної меншини у Воєводині задоволені достатньою мірою. 1 червня 2006 р. українська мова набула статусу регіональної мови національної меншини ${ }^{20}$. Так, Сербія стала першою у світі державою, яка визнала українську мову як регіональну. Українська може офіційно використовуватись у місцевих органах влади, судах, медичних установах, а також у дошкільних, шкільних і вищих навчальних закладах. Предмет «Українська мова 3 елементами національної культури» викладається на відділенні україністики філологічного факультету Белградського

2031 червня українська - офіційна мова у Сербії // Український мовно-інформаційний фонд НАН України. URL: http://www.ulif.org.ua/z-1-chiervnia-ukrayins-kaofitsiina-mova-u-sierbiyi університету та факультативно ${ }^{21}$. Українська мова в університеті вивчається з 1991 р., а відповідну кафедру засновано у 2002 p. ${ }^{22}$

Українська громада в Сербії активно займається культурною діяльністю, про що свідчать фестивалі, народні збори, круглі столи, літні школи україністики. Діячі культурно-мистецьких товариств роблять вагомий внесок у популяризацію української культури, традицій та збереження національної ідентичності української спільноти в Сербіі, на Балканах та світі загалом.

21 Чумак В.В. Україністика в Сербії: лінгвістичний аспект / В. Чумак // Слов’янський збірник. 2003. № 10. C. $17-24$.

22 Атаманюк Ю. Інтерв'ю з Борисом Небесним // Час і події. URL: http://www.chasipodii.net/article/4072/

\section{ДЖЕРЕЛА}

1. Атаманюк Ю. Інтерв’ю з Борисом Небесним. [Електронний ресурс] / Ю. Атаманюк. — 2008. — Режим доступу : http://www.chasipodii.net/article/4072/

2. Гочак М. В Сербії відбулися Дні Тараса Шевченка [Електронний ресурс] / М.В. Гочак. - Режим доступу : http://eukrainians.net/prosvita/sevcenko_mitrovica_06/

3. 31 червня українська - офіційна мова у Сербії. [Електронний ресурс]. - Режим доступу : http://www.ulif.org.ua/z-1-chiervnia-ukrayins-ka-ofitsina-mova-u-sierbiyi

4. Комбіль Я. 3 діяльності Товариства «Просвіта»: Відзначення 100-річчя Товариства «Просвіта»/

Я. Комбіль // Українське слово: Часопис українців у Югославії з питань культури, літератури та суспільного життя. - 2007. — № 13. - С. 32-33.

5. Кулеба Є. Літні школи україністики / Є. Кулеба // Українське слово: Часопис українців у Югославії з питань культури, літератури та суспільного життя. - 2000. - № 7. - С. 26-27.

6. Румянцев О. Становище української громади на території колишньої Югославії з 90-х років XX століття до новіших часів / О. Румянцев // Галичина-Боснія-Воєводина: переселенці з Галичини на території югославських народів в 1890-1990 pp. - 2008. - № 5. - С. 239-243.

7. Саган Г.В. Створення та діяльність товариства української мови, літератури і культури Воєводини (Сербія) / Г.В. Саган // Вісник Черкаського університету. Серія: Історичні науки. 2016. - № 3-4. - С. 130-137.

8. Саган Г.В. Югослов'яни у XX столітті: громадські та культурні зв'язки з Україною / Саган Г.В. ; наук. ред. В.М. Даниленко. - К. : ун-т ім. Б. Грінченка, 2012. - 568 с.

9. Сакач С. Союз руснацох и україцох Югославиї од основаня по нєшка / С. Сакач // Глас Союзу: Союз русинів і українців Сербії і Чорногорії. - 1997. — № 1. - С. $2-5$.

10. Світовий конгрес українців. Сербія. [Електронний ресурс]. - Режим доступу : http:// ukrainianworldcongress.org/news.php/group/31/lang/ua

11. Слово до співвітчизників та друзів. 3 першим числом часопису // Українське слово: часопис українців у Югославії з питань культури, літератури та суспільного життя. -1996. - № 1. C. 7-14.

12. Таблиця перепису населення Сербії в 2011 році. [Електронний ресурс]. - Режим доступу : http://pop-stat.mashke.org/serbia-ethnic2011.htm

13. Терлюк I. Товариство української мови, літератури та культури Воєводини / I. Терлюк // Українське слово: часопис українців у Югославії з питань культури, літератури та суспільного життя. -1996 . - № 1. - С. 38-44.

14. Українці в Сербії. Посольство України в Сербії [Електронний ресурс]. - Режим доступу : http:// serbia.mfa.gov.ua/ua/ukraine-n/ukrainians-in-n

15. Українці Сербії відсвяткували 100-річчя заснування місцевої «Просвіти» [Електронний ресурс]. - 2007.-Режим доступу: http://zakarpattya.net.ua/News/14806-Ukraintsi-Serbii-vidsviatkuvaly100-richchia-zasnuvannia-mistsevoi-Prosvity 
16. Чумак В.В. Україністика в Сербії: лінгвістичний аспект / В. Чумак // Слов’янський збірник. 2003. - № 10. - С. 17-24.

17. 11-й фестиваль української культури «Калина». 2 частина. [Електронний ресурс]. — 2014. — Режим доступу: https://www.ivansenjuk.com/

\section{REFERENCES}

1. Atamaniuk, Yu. (n. d.). Interview with Borys Nebesnyi [in Ukrainian]. http://www.chasipodii.net/ article/4072/

2. Hochak, M. (n. d.). Taras Shevchenko's Days took place in Serbia [in Ukrainian].

http://eukrainians.net/prosvita/sevcenko_mitrovica_06/

3. Since June 1, Ukrainian is the official language in Serbia [in Ukrainian].

http://www.ulif.org.ua/z-1-chiervnia-ukrayins-ka-ofitsiina-mova-u-sierbiyi

4. Kombil, Ya. (2007). Z diialnosti Tovarystva «Prosvita»: Vidznachennia 100-richchia Tovarystva «Prosvita» (From the activity of Prosvita Society: Celebration of the $10^{\text {th }}$ anniversary of Prosvita Society). Ukrainske slovo (Ukrainian Word), (13), 32-33 [in Ukrainian].

5. Kuleba, Ye. (2000). Litni shkoly ukrainistyky (Summer Schools of Ukrainian Studies). Ukrainske slovo (Ukrainian Word), (7), 26-27 [in Ukrainian].

6. Rumiantsev, O. (2008). Stanovyshche ukrainskoi hromady na terytorii kolyshnioi Yuhoslaviyi z 90kh rokiv XX stolittia do novishykh chasiv (The Situation of the Ukrainian Community in the Territory of the Former Yugoslavia since 90 s of the $20^{\text {th }}$ century till the Newest Times. Halychyna-Bosniia-Voievodyna: pereselentsi z Halychyny na terytorii yuhoslavskykh narodiv v 1890-1990 rr. (Galicia-Bosnia-Vojvodina: immigrants from Galicia in the territory of the Yugoslav peoples in 1890-1990s), (5), 239-243 [in Ukrainian]. 7. Sahan, H. (2016). Stvorennia ta diialnist tovarystva ukrainskoi movy, literatury i kultury Voievodyny (Serbiia) (Creation and Activity of the Association of Ukrainian Language, Literature and Culture of Voyevodyna (Serbia). Visnyk cherkaskoho universytetu (3-4), 130-137 [in Ukrainian].

8. Sahan, H. (2012). Yuhosloviany u XX stolitti: hromadski ta kulturni zviazky z Ukrainoiu (Yugoslavia in the $20^{\text {th }}$ century: social and cultural ties with Ukraine). Kyiv: KUBG, 568 p. [in Ukrainian].

9. Sakach, S. (1997). Union of the Rusnats and Ukrainians of Yugoslavia. Glas Soyuzu (Voice of the Union), (1), 2-5 [in Serbian].

10. World Congress of Ukrainians. Serbia. [in Ukrainian]. http://ukrainianworldcongress.org/news.php/ group/31/lang/ua

11. (1996). Word to Compatriots and Friends. Ukrainske slovo (Ukrainian Word), (1), 7-14 [in Ukrainian].

12. Table of Census of the Population of Serbia in 2011 [in Ukrainian]. http://pop-stat.mashke.org/serbiaethnic2011.htm

13. Terliuk, I. (1996). Tovarystvo ukrainskoi movy, literatury ta kultury Voievodyny (Society of Ukrainian Language, Literature and Culture of Voyevodina). Ukrayinske slovo (Ukrainian Word), (1), 38-44 [in Ukrainian].

14. Ukrainians in Serbia. Embassy of Ukraine in Serbia [in Ukrainian].

http://serbia.mfa.gov.ua/ua/ukraine-n/ukrainians-in-n

15. Ukrainians of Serbia celebrated the $100^{\text {th }}$ anniversary of the foundation of the local "Prosvita" [in Ukrainian].

http://zakarpattya.net.ua/News/14806-Ukraintsi-Serbii-vidsviatkuvaly-100-richchia-zasnuvanniamistsevoi-Prosvity

16. Chumak, V. (2003). Ukrayinistyka v Serbiyi: linhvistychnyi aspect (The Ukrainian language in Serbia: the linguistic aspect). Slovianskyi zbirnyk (Slavic collection of works), (10), 17-24 [in Ukrainian].

17. (2014). 11-th festival of Ukrainian culture "Kalina”. Part 2. [in Ukrainian]

https://www.ivansenjuk.com/

\section{Marina Mudrak}

\section{CULTURAL ACTIVITIES OF THE UKRAINIAN DIASPORA IN SERBIA (1991-BEGINNING OF THE $21^{\text {st }}$ CENTURY)}

Today in the Balkans, the community of Ukrainians in Serbia is the largest by its number and importance. Since the 90 s of the $20^{\text {th }}$ century Ukrainian national societies are beginning to be restored and created. The research of their role in Serbia is an important aspect both for studying the history of the Ukrainian diaspora in Serbia and throughout the world. 
Thus, in 1991 a new era for the Ukrainian people begins not only in Ukraine but also abroad. The article highlights the cultural heritage and assets of the Ukrainian diaspora in Serbia from 1991 to 2012, identifies the main directions of activity of cultural and educational organizations, societies, institutions created by Ukrainians in the territory of modern Serbia.

Most of the issues raised in this study did not become the subject of study in the works of Ukrainian and foreign scholars. Our research is based on the memories of members of Ukrainian societies, such as the Society of Ukrainian Language, Literature and Culture "Prosvita" and the I. Seniuk Ukrainian Cultural and Arts Society. Also, the materials of the Embassies of Ukraine in Serbia, the World Congress of Ukrainians, the Information Service of the Prosvita Society and others are included in the article.

The Ukrainian community in Serbia is actively engaged in cultural activities, as evidenced by festivals, national gatherings, round tables, summer schools of Ukrainian studies. The figures of cultural and artistic associations make a significant contribution to the popularization of Ukrainian culture, traditions and preservation of the national identity of the Ukrainian community in Serbia, the Balkans and the world as a whole.

Key words: Ukrainian diaspora in Serbia, cultural and educational activities, cultural relations, Society of Ukrainian language, literature and culture "Prosvita".

Дата надходження статті до редакції: 17.05.2018. 